\title{
The NMR structure of the II-III-VI three-way junction from the Neurospora VS ribozyme reveals a critical tertiary interaction and provides new insights into the global ribozyme structure
}

\author{
ERIC BONNEAU, ${ }^{1}$ NICOLAS GIRARD, ${ }^{1}$ SÉBASTIEN LEMIEUX, ${ }^{2}$ and PASCALE LEGAULT ${ }^{\mathbf{1}}$ \\ ${ }^{1}$ Département de Biochimie et Médecine Moléculaire, Université de Montréal, Montréal, Quebec H3C 3J7, Canada \\ ${ }^{2}$ Département d'Informatique et de Recherche Opérationnelle et Institut de Recherche en Immunologie et en Cancérologie, Université de Montréal, \\ Montréal, Quebec H3C 3J7, Canada
}

\begin{abstract}
As part of an effort to structurally characterize the complete Neurospora VS ribozyme, NMR solution structures of several subdomains have been previously determined, including the internal loops of domains I and VI, the I/V kissing-loop interaction and the III-IV-V junction. Here, we expand this work by determining the NMR structure of a 62-nucleotide RNA (J236) that encompasses the VS ribozyme II-III-VI three-way junction and its adjoining stems. In addition, we localize $\mathrm{Mg}^{2+}$-binding sites within this structure using $\mathrm{Mn}^{2+}$-induced paramagnetic relaxation enhancement. The NMR structure of the J236 RNA displays a family C topology with a compact core stabilized by continuous stacking of stems II and III, a cis WC/WC G・A base pair, two base triples and two $\mathrm{Mg}^{2+}$ ions. Moreover, it reveals a remote tertiary interaction between the adenine bulges of stems II and VI. Additional NMR studies demonstrate that both this bulge-bulge interaction and $\mathrm{Mg}^{2+}$ ions are critical for the stable folding of the II-III-VI junction. The NMR structure of the J236 RNA is consistent with biochemical studies on the complete VS ribozyme, but not with biophysical studies performed with a minimal II-III-VI junction that does not contain the II-VI bulge-bulge interaction. Together with previous NMR studies, our findings provide important new insights into the threedimensional architecture of this unique ribozyme.
\end{abstract}

Keywords: Varkud satellite ribozyme; NMR structure; RNA three-way junction; remote tertiary interaction; magnesium ions

\section{INTRODUCTION}

The Varkud satellite (VS) ribozyme is a member of the family of small nucleolytic ribozymes that includes the hairpin, hammerhead, hepatitis delta virus, glms, and twister ribozymes (Saville and Collins 1990; Collins 2002; Lilley 2004, 2008; Cochrane and Strobel 2008; Wilson and Lilley 2011; Roth et al. 2014). The VS ribozyme is derived from a noncoding satellite RNA found in the mitochondria of certain natural isolates of Neurospora filamentous fungi (Saville and Collins 1990). It catalyzes self-cleavage and self-ligation at a specific phosphodiester bond, and both of these transesterification reactions are critical for the replication cycle of the VS RNA (Saville and Collins 1990, 1991). In vitro, these reactions require the presence of metal cations, which are important for both the structure and the chemical reaction (Collins and Olive 1993; Beattie et al. 1995; Beattie and Collins 1997; Murray et al. 1998; Sood et al. 1998; Hiley

Corresponding author: pascale.legault@umontreal.ca

Article published online ahead of print. Article and publication date are at http://www.rnajournal.org/cgi/doi/10.1261/rna.052076.115. and Collins 2001; Maguire and Collins 2001; Sood and Collins 2002; Smith et al. 2008). The minimal contiguous VS ribozyme is composed of six helical domains, numbered I-VI (Beattie et al. 1995). Stem-loop I (SLI) forms the substrate domain, and its internal loop contains the cleavage site. Helical domains II-VI constitute the catalytic domain, also termed the trans ribozyme, which is organized around two three-way junctions: the II-III-VI and III-IV-V junctions (Fig. 1A; Beattie et al. 1995). The SLI substrate domain is recognized by stem-loop V (SLV) through the formation of a highly stable kissing-loop interaction, which has been extensively characterized (Rastogi et al. 1996; Andersen and Collins 2000, 2001; Bouchard and Legault 2014a,b). In particular, this kissing-loop interaction is associated with a conformational change in the internal loop of SLI that activates

(C) 2015 Bonneau et al. This article is distributed exclusively by the RNA Society for the first 12 months after the full-issue publication date (see http://rnajournal.cshlp.org/site/misc/terms.xhtml). After 12 months, it is available under a Creative Commons License (Attribution-NonCommercial 4.0 International), as described at http://creativecommons.org/licenses/ by-nc/4.0/. 

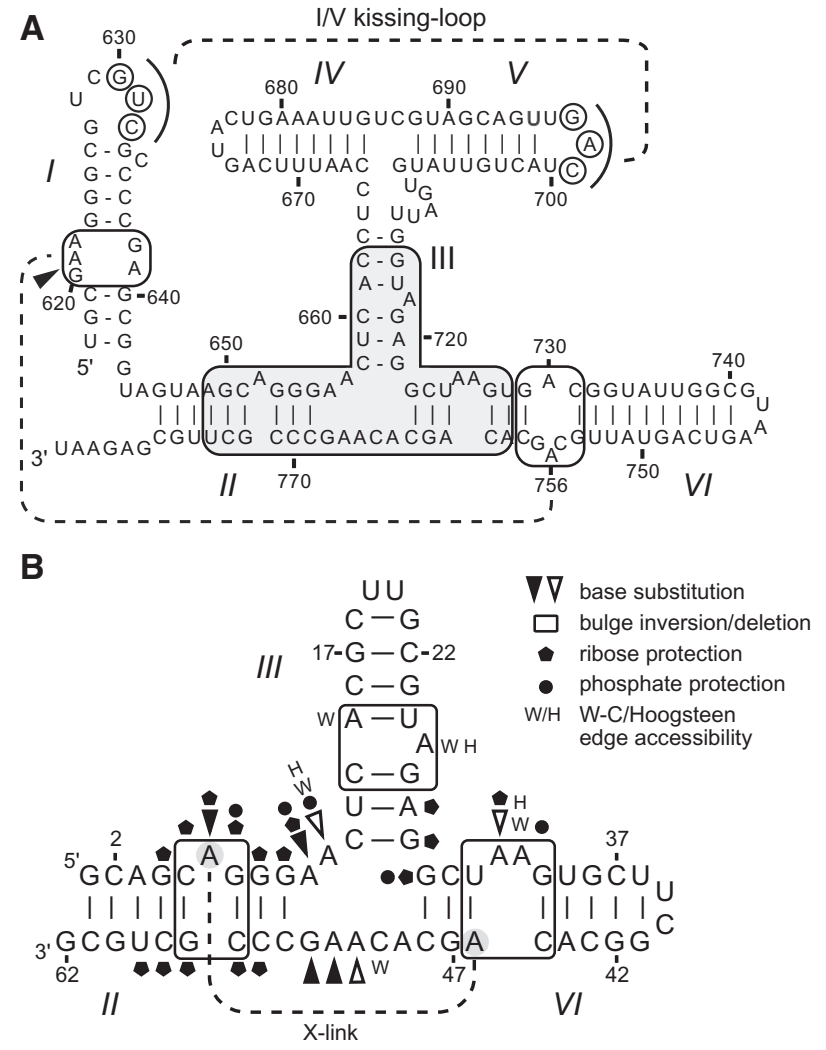

FIGURE 1. Primary and secondary structures of a cis-cleaving VS ribozyme (including residues 617-783) (Beattie et al. 1995) (A) and the 62nt J236 RNA used in this study with a summary of biochemical data $(B)$. In $A$, the substrate is shown in its active conformation (Andersen and Collins 2000), with the cleavage site indicated by a gray arrowhead. Dashed lines represent tertiary interactions involving the SLI substrate. Gray shading is used to highlight the residues from the II-III-VI junction that are present in the J236 RNA. In $B$, the filled and open arrowheads represent residues for which site-specific base substitution decreases the activity of the ribozyme by $\geq 20$-fold and $<20$-fold, respectively (Lafontaine et al. 2001a,b; Sood and Collins 2002; McLeod and Lilley 2004). The gray boxes highlight A-rich bulges for which deletion of the bulge and/or strand inversion decreases the activity of the ribozyme by $\geq 20$-fold (Lafontaine et al. 2001b, 2002; Sood and Collins 2002). The black pentagons and circles indicate residues that have their ribose and $5^{\prime}$-phosphate groups protected from hydroxyl radical and ENU modifications, respectively, under native conditions (Sood et al. 1998; Hiley and Collins 2001; Sood and Collins 2002). The W and H letters indicate residues that have their Watson-Crick and Hoogsteen edges accessible to chemical probing under native conditions (Beattie et al. 1995; Beattie and Collins 1997; Maguire and Collins 2001; Sood and Collins 2002). The dashed line represents formation of a UV crosslink between the two residues shaded in light gray (Sood and Collins 2002).

the substrate for catalysis (Andersen and Collins 2000, 2001; Bouchard and Legault 2014b). Similarly to the hairpin ribozyme, the VS ribozyme active site is formed by the interaction of two internal loops: the cleavage site internal loop of SLI and the A730 internal loop of stem-loop VI (SLVI) (Wilson et al. 2007; Lilley 2008; Desjardins et al. 2011; Wilson and Lilley 2011). In addition, the internal loops of SLI and SLVI each contain a key catalytic residue $\left(\mathrm{G}_{638}\right.$ and $\mathrm{A}_{756}$ ) that contribute to the proposed general acid-base mechanism (Jones and Strobel 2003; McLeod and Lilley 2004; Zhao et al. 2005; Smith and Collins 2007; Wilson et al. 2007, 2010; Jaikaran et al. 2008; Smith et al. 2008).

Although no complete high-resolution structure has been reported for the VS ribozyme, low-resolution models have been derived from biochemical, fluorescence resonance energy transfer (FRET), and small-angle X-ray scattering (SAXS) studies that provide insights into its global structure (Hiley and Collins 2001; Lafontaine et al. 2001a, 2002; Lipfert et al. 2008). Moreover, several high-resolution NMR structures of isolated subdomains of the Neurospora VS ribozyme have been determined, including the structures of the SLI substrate in its inactive (Michiels et al. 2000; Flinders and Dieckmann 2001) and active forms (Hoffmann et al. 2003), the terminal loop of SLV in the presence and absence of magnesium ions $\left(\mathrm{Mg}^{2+}\right)$ (Campbell and Legault 2005; Campbell et al. 2006), the I/V kissing-loop interaction (Bouchard and Legault 2014b), the A730 loop of SLVI (Flinders and Dieckmann 2004; Desjardins et al. 2011; Bonneau and Legault 2014a), and the III-IV-V three-way junction (Bonneau and Legault 2014b). Our laboratory has contributed significantly to determining NMR structures of VS ribozyme subdomains with the goal of defining a complete high-resolution solution structure of the Neurospora VS ribozyme. The only significant domain that remains to be structurally characterized is the II-III-VI three-way junction.

The II-III-VI junction is a key architectural domain (Fig. 1A) that is essential for the activity of the VS ribozyme; it orients the A730 loop of SLVI in such a way that it can form the active site with SLI (Lafontaine et al. 2001a, 2002; Sood and Collins 2002). Substitutions and chemical modifications of several residues within the junction significantly decrease the catalytic activity of the VS ribozyme, and several of these residues are protected from chemical modifications under native conditions (Fig. 1B). Together, these results indicate that the II-III-VI junction adopts a well-defined compact structure. Interestingly, substitution of the II-III-VI junction by a rRNA junction of similar sequence leads to a 10 -fold reduction in the cleavage rate, suggesting that these junctions may share structural characteristics (Lafontaine et al. 2001a). Moreover, bioinformatic (Lescoute and Westhof 2006; Tyagi and Mathews 2007) and biophysical (Lafontaine et al. 2001a) studies of the II-III-VI junction suggest that it adopts a family A topology with coaxial stacking of stems III and VI (Lafontaine et al. 2001a; Lescoute and Westhof 2006; Tyagi and Mathews 2007). In contrast, a more recent bioinformatic study proposed a family $\mathrm{C}$ topology with coaxial stacking of stems II and III (Laing et al. 2012). Thus, there is a lack of consensus at this time on the basic topology of the IIIII-VI junction within the VS ribozyme. In addition, although the adenine bulges of the adjoining stems have been shown to contribute to the activity and likely to the global structure of the VS ribozyme, it is not clear if they play a role in defining the II-III-VI junction (Lafontaine et al. 2001b, 2002; Sood and Collins 2002; McLeod and Lilley 2004). Similarly, 
although divalent metal ions have been shown to stabilize the II-III-VI junction (Beattie et al. 1995; Sood et al. 1998; Hiley and Collins 2001; Lafontaine et al. 2001a; Maguire and Collins 2001; Sood and Collins 2002; Pereira et al. 2008), their precise role remains unknown.

In this study, we investigate the NMR solution structure of a 62-nucleotide (nt) RNA (J236) that encompasses the VS ribozyme II-III-VI junction and its three adjoining stems, each one containing its natural adenine bulge (Fig. 1B). Furthermore, we localize $\mathrm{Mg}^{2+}$-binding sites within the J236 RNA using manganese $\left(\mathrm{Mn}^{2+}\right)$-induced paramagnetic relaxation enhancement (PRE) (Bonneau and Legault 2014a). The NMR structure of J236 reveals that the II-III-VI junction belongs to the family $\mathrm{C}$ of threeway junctions, with a complex network of interactions at the junction and helical stacking of stems II and III. We also identify a remote tertiary interaction between the adenine bulges of stems II and VI that stabilizes the structure of the II-III-VI junction. In combination with the wealth of information available from previous NMR studies of isolated subdomains, the NMR structure of J236 provides important new insights into the global three-dimensional structure of the Neurospora VS ribozyme.

\section{RESULTS}

\section{The J236 RNA adopts a stable structure in the presence of $\mathbf{M g}^{2+}$ ions}

We first investigated the effect of $\mathrm{Mg}^{2+}$ ions on the structure of the J236 RNA using ${ }^{1} \mathrm{H}-{ }^{15} \mathrm{~N}$ heteronuclear NMR methods. In the presence of $5 \mathrm{mM} \mathrm{MgCl}_{2}$, the $2 \mathrm{D}{ }^{1} \mathrm{H}-{ }^{15} \mathrm{~N}$ HSQC spectrum (Fig. 2A) is well dispersed with detectable signals for 25 of the 28 imino groups, which is consistent with the formation of a unique stable structure for J236. By comparison, the $2 \mathrm{D}{ }^{1} \mathrm{H}-{ }^{15} \mathrm{~N}$ HSQC spectrum of $\mathrm{J} 236$ collected in the absence of $\mathrm{Mg}^{2+}$ ions is considerably different and contains fewer high-intensity signals (Fig. 2B). These results indicate that formation of a stable II-III-VI junction is dependent on $\mathrm{Mg}^{2+}$ ions, in agreement with previous biochemical and FRET studies (Beattie et al. 1995; Sood et al. 1998; Hiley and Collins 2001; Lafontaine et al. 2001a; Maguire and Collins 2001; Sood and Collins 2002; Pereira et al. 2008). Interestingly, an imino signal with an unusual ${ }^{15} \mathrm{~N}$ chemical shift is ob-
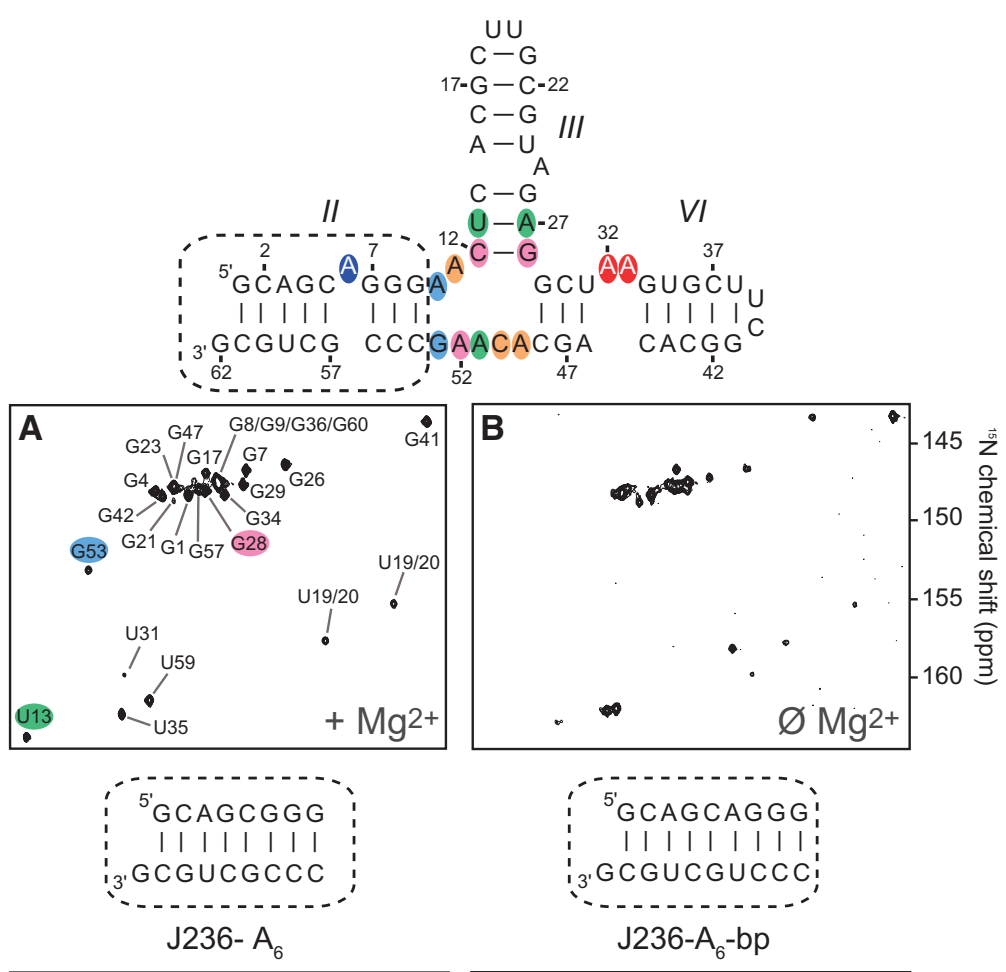

FGURE 2. The J236 RNA adopts a stable structure that requires $\mathrm{Mg}^{2+}$ ions and an intact bulge in stem II. $(A, B) 2 \mathrm{D}^{1} \mathrm{H}-{ }^{15} \mathrm{~N}$ HSQC spectra of the J236 RNA in the presence $(A)$ and absence $(B)$ of 5 $\mathrm{mM} \mathrm{MgCl} 2$. (Above $A, B)$ Primary and secondary structures of $\mathrm{J} 236$ with shading of residues colorcoded according to structural elements present in the NMR structure (see Fig. 3). (C,D) 2D

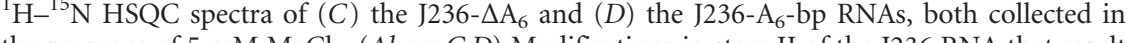
the presence of $5 \mathrm{mM} \mathrm{MgCl}_{2}$. (Above $C, D$ ) Modifications in stem II of the J236 RNA that result in the J236- $\triangle \mathrm{A}_{6}$ and the J236- $\mathrm{A}_{6}$-bp RNAs.

served for $\mathrm{G}_{53}$ only in the presence of $\mathrm{Mg}^{2+}$ ions (Fig. 2A), and a $2 \mathrm{D} H N N-C O S Y$ spectrum reveals that this residue forms a WC/WC G•A base pair within the junction (data not shown). Furthermore, a network of NOEs is observed between $\mathrm{G}_{53}$ and both $\mathrm{G}_{9}$ of stem II and $\mathrm{G}_{28}$ of stem III (data not shown), suggesting stacking between stems II and III as part of a highly organized junction.

Three-way junctions are generally stabilized by remote tertiary interactions that involve residues from adjacent stems (de la Pena et al. 2009). To test for the presence of a remote tertiary interaction in the II-III-VI junction, we recorded 2D ${ }^{1} \mathrm{H}-{ }^{15} \mathrm{~N}$ HSQC spectra of two variants of J236 in which the stem II bulge was removed, either by the deletion of $\mathrm{A}_{6}$ (J236- $\Delta \mathrm{A}_{6}$ RNA; Fig. $2 \mathrm{C}$ ) or by the insertion of a $\mathrm{U}$ residue 
on the opposite strand to form an $\mathrm{A}-\mathrm{U}$ base pair (J236- $\mathrm{A}_{6}$-bp RNA; Fig. 2D). The NMR data indicate that these variants do not adopt a stable fold even in the presence of $\mathrm{Mg}^{2+}$ ions (Fig. 2C,D). Thus, the $\mathrm{A}_{6}$ bulge of stem II plays an important role in stabilizing the structure of the II-III-VI junction, possibly by mediating a remote interaction with stem VI.

\section{The overall NMR structure of the J236 RNA}

The high-resolution solution structures of the J236 RNA were determined in the presence of $\mathrm{Mg}^{2+}$ ions using heteronuclear NMR spectroscopy of uniformly labeled $\left({ }^{15} \mathrm{~N}\right.$ or $\left.{ }^{13} \mathrm{C} /{ }^{15} \mathrm{~N}\right)$ and selectively labeled (with ${ }^{13} \mathrm{C} /{ }^{15} \mathrm{~N}$-labeled $\mathrm{A}, \mathrm{C}$ or $\mathrm{G}$ residues) J236 RNAs. This labeling strategy allowed for almost complete assignments of the observable resonances $\left({ }^{1} \mathrm{H},{ }^{15} \mathrm{~N}\right.$, and $\left.{ }^{13} \mathrm{C}\right)$ of the bases and the $\mathrm{C1}^{\prime}-\mathrm{H}^{\prime}, \mathrm{C}^{\prime}-\mathrm{H} 2^{\prime}, \mathrm{C}^{\prime}-\mathrm{H} 3^{\prime}$, and $\mathrm{C} 4^{\prime}-$ $\mathrm{H} 4^{\prime}$ resonances of the ribose moieties. Experiments on selectively labeled J236 RNAs were particularly valuable for analysis of NMR data given that J236 is larger than $60 \mathrm{nt}$. In fact, only a few NMR structures are available for such larger RNAs (Lukavsky et al. 2003; D'Souza et al. 2004; Miyazaki et al. 2010; Burke et al. 2012; Miller et al. 2014; Keane et al. 2015).

Three-dimensional structures of J236 were initially determined using NOE-derived distance restraints and dihedral angle restraints. Subsequently, structures of J236 were calculated with bound $\mathrm{Mg}^{2+}$ ions ( $\left(236^{\mathrm{Mg}}\right.$ ) by adding metal-RNA restraints derived from $\mathrm{Mn}^{2+}$-induced PRE to the existing set of experimental restraints (Bonneau and Legault 2014a,b). Due to these additional restraints, the $J 236^{\mathrm{Mg}}$ structure (Fig. 3) is better defined than the original J236 structure with heavy atom RMSD values that are lower for the overall structure $(2.95 \pm 0.73 \AA$ versus $3.97 \pm 1.51 \AA)$ as well as for local structural elements $(\leq 1.4 \AA$ versus $\leq 1.8 \AA$; Table 1$)$. Thus, the $J 236^{\mathrm{Mg}}$ structure represents a high-resolution structure with well-defined local structural elements and is presented in detail, although similar observations were made with the J236 structure.

The J236 ${ }^{\mathrm{Mg}} \mathrm{RNA}$ adopts a Y-shaped fold that belongs to the family C of three-way junctions (Lescoute and Westhof 2006), with a well-defined core domain (RMSD of $0.67 \pm 0.10 \AA$; Table 1; Fig. 3) that orients stems II and VI side-by-side and away from stem III. Stems II and VI define an acute interhelical angle $\left(\varphi_{\mathrm{II}-\mathrm{VI}}=77.5^{\circ} \pm 10.0^{\circ}\right)$, whereas the other two stem pairs define obtuse interhelical angles $\left(\varphi_{\mathrm{II}-\mathrm{III}}=127.0^{\circ} \pm 7.9^{\circ}\right.$ and $\left.\varphi_{\text {III-VI }}=149.3^{\circ} \pm 9.6^{\circ}\right)$. The orientation of stems II and VI allows for the formation of a remote interaction between the $\mathrm{A}_{6}$ bulge of stem II and the $\mathrm{A}_{32} \mathrm{~A}_{33}$ bulge of stem VI.

The $J 236^{\mathrm{Mg}}$ structure contains a total of eight $\mathrm{Mg}^{2+}$-binding sites that were identified based on $\mathrm{Mn}^{2+}$-induced PRE and modeled as hexahydrated $\mathrm{Mg}^{2+}$ complexes $\left[\mathrm{Mg}\left(\mathrm{H}_{2} \mathrm{O}\right)_{6}^{2+}\right]$ (Fig. 3B; Table 2). As detailed below, several of these sites are associated with structural elements that stabilize the IIIII-VI junction. It is important to note that the PRE studies do not provide information about the occupancy of the $\mathrm{Mg}^{2+}$ ions at these sites, but simply reveal preferential sites for $\mathrm{Mg}^{2+}$ binding (Bonneau and Legault 2014b). Accordingly, several residues within the J236 core and bulge-bulge interaction display ${ }^{1} \mathrm{H}-{ }^{13} \mathrm{C}$ and ${ }^{1} \mathrm{H}-{ }^{15} \mathrm{~N}$ correlation signals of either relatively low intensity $\left(C_{5}, A_{6}, A_{10}, C_{12}, U_{13}, C_{30}, U_{31}\right.$, $\mathrm{C}_{45}, \mathrm{~A}_{51}, \mathrm{~A}_{52}$, and $\mathrm{G}_{53}$ ) or that correspond to two populations in slow exchange $\left(G_{7}\right)$, suggestive of conformational exchanges associated with $\mathrm{Mg}^{2+}$-ion binding.

\section{The core of the J236 RNA adopts a compact structure}

The core of $1236^{\mathrm{Mg}}$ adopts a well-defined structure, in which stems II and III form a continuous helical segment that excludes $A_{11}$ (Fig. 4). In contrast, the stacking is disrupted 


\begin{tabular}{|c|c|c|c|}
\hline Site & $\begin{array}{l}\text { Outer-sphere } \\
\text { ligands }^{\mathrm{a}}\end{array}$ & $\begin{array}{l}\text { Electrostatic } \\
\text { interactions }\end{array}$ & $\begin{array}{l}\text { Cation- } \pi \\
\text { interactions }^{\mathrm{c}}\end{array}$ \\
\hline Site 1 & $\begin{array}{l}\mathrm{G}_{36} \mathrm{O} 6 \\
\mathrm{G}_{36} \mathrm{~N} 7 \\
\mathrm{G}_{36} 5^{\prime}-\text { pro- } \mathrm{R}_{\mathrm{p}} \mathrm{OP}\end{array}$ & $\mathrm{G}_{36} 5^{\prime}-\mathrm{PO}_{4}^{-}$ & \\
\hline Site 2 & $\begin{array}{l}\mathrm{A}_{6} \mathrm{O} 2^{\prime} \\
\mathrm{G}_{34} \mathrm{O} 6 \\
\mathrm{G}_{34} \mathrm{~N} 7\end{array}$ & $\begin{array}{l}\mathrm{G}_{7} 5^{\prime}-\mathrm{PO}_{4}^{-} \\
\mathrm{G}_{34} 5^{\prime}-\mathrm{PO}_{4}^{-}\end{array}$ & \\
\hline Site 3 & $\begin{array}{l}\mathrm{A}_{46} \mathrm{N7} \\
\mathrm{G}_{47} \mathrm{O} 6 \\
\mathrm{G}_{47} \mathrm{N7}\end{array}$ & $\begin{array}{ll}\mathrm{C}_{5} & 5^{\prime}-\mathrm{PO}_{4}^{-} \\
\mathrm{A}_{6} & 5^{\prime}-\mathrm{PO}_{4}^{-} \\
\mathrm{A}_{46} & 5^{\prime}-\mathrm{PO}_{4}^{-} \\
\mathrm{G}_{47} & 5^{\prime}-\mathrm{PO}_{4}^{-}\end{array}$ & \\
\hline Site 4 & $\begin{array}{l}\mathrm{A}_{49} \mathrm{O}^{\prime} \\
\mathrm{G}_{53} 5^{\prime} \text {-pro- } \mathrm{R}_{\mathrm{p}} \mathrm{OP}\end{array}$ & $\begin{array}{ll}\mathrm{A}_{52} & 5^{\prime}-\mathrm{PO}_{4}^{-} \\
\mathrm{G}_{53} & 5^{\prime}-\mathrm{PO}_{4}^{-} \\
\mathrm{C}_{54} & 5^{\prime}-\mathrm{PO}_{4}^{-}\end{array}$ & \\
\hline Site 5 & $\begin{array}{l}\mathrm{G}_{26} 5^{\prime}-\text { pro- } \mathrm{R}_{\mathrm{p}} \mathrm{OP} \\
\mathrm{G}_{26} \text { O6 } \\
\mathrm{G}_{26} \mathrm{~N} 7 \\
\mathrm{~A}_{27} \mathrm{~N} 7\end{array}$ & $\begin{array}{ll}\mathrm{A}_{25} & 5^{\prime}-\mathrm{PO}_{4}^{-} \\
\mathrm{G}_{26} & 5^{\prime}-\mathrm{PO}_{4}^{-}\end{array}$ & \\
\hline Site 6 & $\begin{array}{l}\mathrm{G}_{17} \mathrm{O} 6 \\
\mathrm{G}_{21} \mathrm{O} 6 \\
\mathrm{G}_{21} \mathrm{~N} 7\end{array}$ & & \\
\hline Site 7 & $\begin{array}{l}\mathrm{G}_{9} 5^{\prime}-\text { pro- } \mathrm{R}_{\mathrm{p}} \text { OP } \\
\mathrm{G}_{9} \mathrm{~N} 7 \\
\mathrm{~A}_{10} \mathrm{N7} \\
\mathrm{G}_{28} \mathrm{O} 2^{\prime} \\
\mathrm{G}_{53} \mathrm{O} 6\end{array}$ & $\begin{array}{l}\mathrm{G}_{9} 5^{\prime}-\mathrm{PO}_{4}^{-} \\
\mathrm{A}_{10} 5^{\prime}-\mathrm{PO}_{4}^{-} \\
\mathrm{G}_{29} 5^{\prime}-\mathrm{PO}_{4}^{-}\end{array}$ & \\
\hline Site 8 & $\begin{array}{l}\mathrm{G}_{7} \mathrm{O} 6 \\
\mathrm{G}_{57} \mathrm{O} 6\end{array}$ & $\mathrm{~A}_{6} 5^{\prime}-\mathrm{PO}_{4}^{-}$ & $\mathrm{C}_{5}$ \\
\hline
\end{tabular}

$\overline{{ }^{a} O u t e r-s p h e r e ~ l i g a n d s ~ w e r e ~ d e t e r m i n e d ~ b y ~ s e l e c t i n g ~ a l l ~ h y d r o g e n-~}$ bond acceptors within $4.0 \AA$ of a $\mathrm{Mg}\left(\mathrm{H}_{2} \mathrm{O}\right)_{6}^{2+}$ oxygen and in a favorable orientation for outer-sphere interactions in at least $25 \%$ of the lowest-energy structures presenting an occupancy at a site.

${ }^{b}$ Electrostatic interactions were determined by selecting $5^{\prime}-\mathrm{PO}_{4}^{-}$ within $8.0 \AA$ of $\mathrm{a} \mathrm{Mg}^{2+}$ ion.

${ }^{\mathrm{c} C}$ Cation- $\pi$ interactions were determined for $\mathrm{Mg}^{2+}$ ions within 5.2 $\AA$ and at an angle smaller than $52^{\circ}$ from the ring centroid (McFailIsom et al. 1998).

between stems III and VI, with $\mathrm{G}_{28}$ and $\mathrm{G}_{29}$ being stacked on their respective stems, but in a splayed conformation relative to each other that creates an abrupt turn in the phosphate backbone (Figs. 3, 4). The longest single-stranded region in the junction connects stems II and VI and contains a backbone turn involving residues $\mathrm{A}_{49}, \mathrm{C}_{50}, \mathrm{~A}_{51}$, and $\mathrm{A}_{52}$ (Fig. 4). Within this ACAA turn, there is continuous stacking between $\mathrm{C}_{50}, \mathrm{~A}_{49}$, and $\mathrm{C}_{48}$ of stem VI, whereas the backbone is reversed after $\mathrm{C}_{50}$ to allow for continuous stacking between $A_{51}, A_{52}, G_{53}$, and $C_{54}$ of stem II. Although the ACAA turn is reminiscent of a U-turn, it does not display as sharp of a backbone reversal as a U-turn and is stabilized by only one hydrogen bond $\left(\mathrm{C}_{50} 2^{\prime}\right.$-OH to $\left.\mathrm{A}_{51} \mathrm{~N} 7\right)$ that has no equivalent in U-turn structures (Fig. 4; Campbell et al. 2006). Nevertheless, the ACAA turn of J236 positions the bases of $A_{51}$ and $A_{52}$ to interact with the minor groove of stem III, and this positioning of bases for tertiary contacts is typical of the U-turn motif (von Ahsen et al. 1997; Lambert et al. 2006; de la Pena et al. 2009; Bonneau and Legault 2014b; Bouchard and Legault 2014b).

The core of the three-way junction within $2236^{\mathrm{Mg}}$ is stabilized by a cis WC/WC G・A base pair and two minor groove base triples (Fig. 5). The $\left(\mathrm{U}_{13}-\mathrm{A}_{27}\right) \cdot \mathrm{A}_{51}$ base triple (RMSD of $0.51 \pm 0.10 \AA$ ) is formed by the interaction of the WC edge of $A_{51}$ with the minor groove of the $W C U_{13}-A_{27}$ base pair, whereas the $\left(\mathrm{C}_{12}-\mathrm{G}_{28}\right) \cdot \mathrm{A}_{52}$ base triple (RMSD of 0.53 $\pm 0.17 \AA$ ) involves the WC edge of $A_{52}$ and the minor groove of the WC $\mathrm{C}_{12}-\mathrm{G}_{28}$ base pair. The $\left(\mathrm{C}_{12}-\mathrm{G}_{28}\right) \cdot \mathrm{A}_{52}$ base triple stacks with the $\left(\mathrm{U}_{13}-\mathrm{A}_{27}\right) \cdot \mathrm{A}_{51}$ base triple on one side and with the well-defined cis WC/WC $\mathrm{A}_{10}{ }^{\circ} \mathrm{G}_{53}$ base pair (RMSD of $0.33 \pm 0.15 \AA$ ) on the other side to allow for continuous stacking between stems II and III.

Two $\mathrm{Mg}^{2+}$ ions interact with the core domain (Fig. 4; Table 2) that are both associated with the $A_{10}{ }^{\circ} G_{53}$ base pair. The $\mathrm{Mg}^{2+}$ ion at Site 4 is located at the $\mathrm{A}_{49} \mathrm{C}_{50} \mathrm{~A}_{51} \mathrm{~A}_{52}$ turn, making outer-sphere interactions with both $\mathrm{A}_{49}$ and $\mathrm{G}_{53}$ and stabilized by electrostatic interactions with the $5^{\prime}$-phosphates of $\mathrm{A}_{52}, \mathrm{G}_{53}$, and $\mathrm{C}_{54}$. The $\mathrm{Mg}^{2+}$ ion at Site 7 is located within the major groove of stem II, making outer-sphere contacts with $G_{9}, A_{10}, G_{28}$, and $G_{53}$ and stabilized by electrostatic interactions with the 5'-phosphates of $\mathrm{G}_{9}, \mathrm{~A}_{10}$, and $\mathrm{G}_{29}$. Although the $\mathrm{Mg}^{2+}$ ion at Site 7 may play a specific role in stabilizing the sharp backbone turn at the $\mathrm{G}_{28}-\mathrm{G}_{29}$ dinucleotide step, both of these $\mathrm{Mg}^{2+}$ ions are likely important for the compact structure at the II-III-VI junction.

\section{A remote tertiary interaction between stems II and VI}

The NMR structure of $236^{\mathrm{Mg}}$ also reveals a remote tertiary interaction in which the $A_{6}$ bulge from stem II interacts with the $\mathrm{A}_{32} \mathrm{~A}_{33}$ bulge of stem VI (Fig. 6A, left panel). In this bulge-bulge interaction, $A_{6}$, which protrudes from stem II, forms two hydrogen bonds with $\mathrm{A}_{32}$ to adopt a cis Sugar edge/WC $\mathrm{A}_{6} \cdot \mathrm{A}_{32}$ base pair (RMSD of $0.80 \pm 0.24 \AA$ ) (Fig. 6B). In addition, the base of $A_{6}$ is sandwiched between the bases of residues $\mathrm{C}_{45}$ and $\mathrm{A}_{46}$ in stem VI (Fig. 6A, right panel). This tertiary interaction may be facilitated by the $\mathrm{S}$ turn motif centered at the $\mathrm{A}_{32} \mathrm{~A}_{33}$ bulge (Fig. $6 \mathrm{~A}$, right panel), which involves the backbone reversal and the 2 -endo conformation of the $\mathrm{A}_{32}$ ribose and the exclusion of $\mathrm{A}_{33}$ from stem VI (Correll et al. 1997; Desjardins et al. 2011). It is important to note that this bulge-bulge interaction is well defined by the NMR data and that we did not include any explicit hydrogen bonding restraint to define the $\mathrm{A}_{6} \cdot \mathrm{A}_{32}$ base pair. Instead, two critical NOE interactions were observed that helped define the geometry of the $A_{6} \cdot A_{32}$ base pair: $A_{32} H 2$ to $\mathrm{A}_{6} \mathrm{H}^{\prime}$ and $\mathrm{A}_{32} \mathrm{H} 2$ to $\mathrm{A}_{6} \mathrm{H} 4^{\prime}$ (Fig. 6C). Several additional NOEs were observed that allow us to define a total of 19 unique distance restraints between stems II and IV at the bulge-bulge interaction.

Three $\mathrm{Mg}^{2+}$-binding sites were identified near the bulgebulge interaction. The $\mathrm{Mg}^{2+}$ ions at Sites 2 and 3 interact with residues of both stems II and VI, whereas the $\mathrm{Mg}^{2+}$ 
A
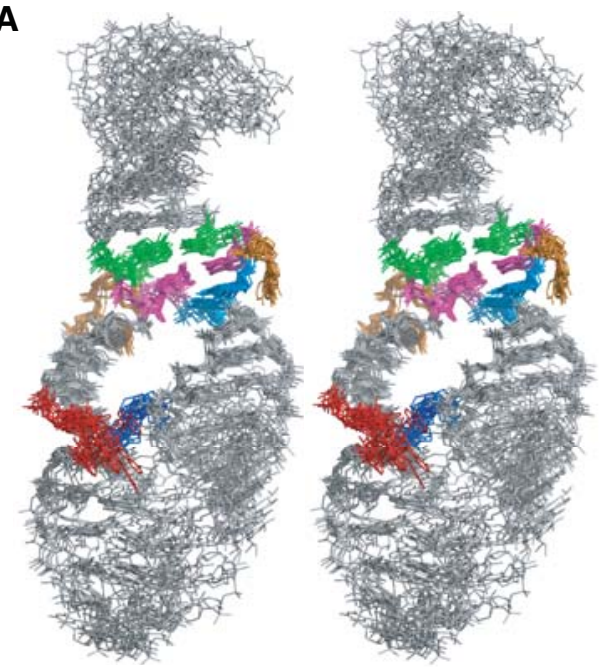

B

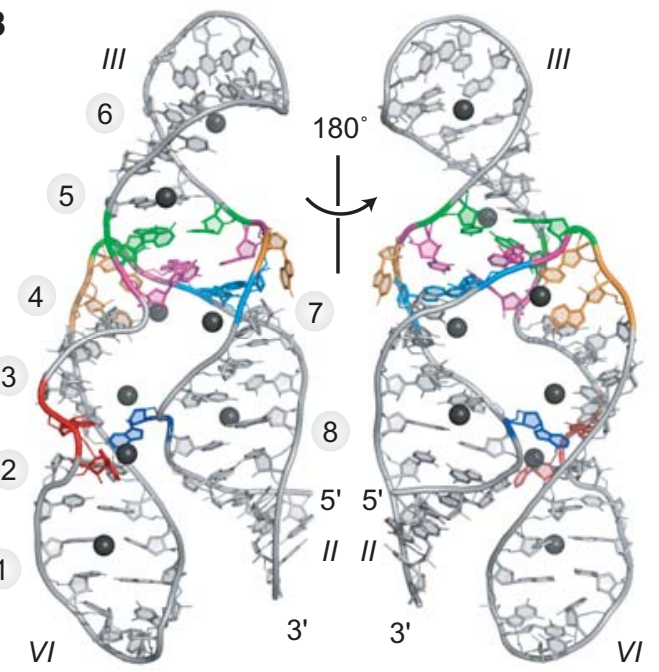

C $\cup \cup$ $G \rightarrow C$ $22-C \bullet-G-17$ $G \rightarrow C \quad I I I$

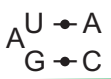
27- $A \rightarrow U \leftrightarrow A$

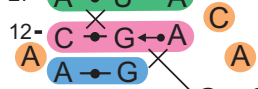
$G \leftrightarrow C \quad G \rightarrow C$ $G \rightarrow C \quad C \rightarrow G-47$ $C \rightarrow G-7 \quad U \rightarrow A$ $57-G \rightarrow C \stackrel{A}{A} \AA_{G \rightarrow-C}$ $C \rightarrow G \quad G \rightarrow C$ $I I \quad U \rightarrow A \quad U \rightarrow A \quad V I$ $G \rightarrow C-2 \quad G \rightarrow C$ VI $C \rightarrow G^{37-C \rightarrow-G-42}$ $\underset{3,}{62-G} 5^{\prime} \quad U \rightarrow-G$

FIGURE 3. NMR solution structure of the J236 ${ }^{\mathrm{Mg}}$ RNA. (A) Stereoview of the 10 lowest-energy structures of $J 236^{\mathrm{Mg}}$. Only heavy atoms of residues 2-60 are included in the superposition. For clarity, the $\mathrm{Mg}^{2+}$ ions were omitted. (B) Stick representations of the lowest-energy structure of $\mathrm{J}_{236}{ }^{\mathrm{Mg}}$ (residues 1-61), with the $\mathrm{Mg}^{2+}$ ions (dark gray spheres) numbered 1-8. (C) Schematic representation of the tertiary structure of $236^{\mathrm{Mg}}$ derived from the NMR structure. Canonical and noncanonical base pairs are represented using the Leontis-Westhof notation (Leontis and Westhof 2001; Abu Almakarem et al. 2012). In $A-C$, residues are color-coded according to structural elements: the $\left(U_{13}-A_{27}\right) \cdot A_{51}$ base triple in green, the $\left(C_{12}-G_{28}\right) \cdot A_{52}$ base triple in magenta, the $A_{10}{ }^{\circ} G_{53}$ base pair in light blue, the unpaired residues of the core $\left(A_{11}, A_{49}\right.$, and $\left.C_{50}\right)$ in orange, the $\mathrm{A}_{6}$ bulge of stem II in dark blue, and the $\mathrm{A}_{32} \mathrm{~A}_{33}$ bulge of stem VI in red.

ion at Site 8 interacts with stem II near the $\mathrm{A}_{6}$ bulge (Fig. 6A; Table 2). It is likely that these three $\mathrm{Mg}^{2+}$ ions stabilize the formation of the II-VI bulge-bulge interaction by counteracting the negative charges carried by the backbones of stems II and VI.

\section{DISCUSSION}

Our NMR studies of J236 reveal that the II-III-VI junction of the VS ribozyme forms a compact core as well as a bulgebulge interaction between stems II and VI. The integrity of the structure depends on both the formation of this remote tertiary interaction and the presence of $\mathrm{Mg}^{2+}$ ions. These new findings are discussed below in light of previous biochemical and biophysical studies of the VS ribozyme. Being the final piece of the puzzle in our quest to characterize isolated subdomains of the Neurospora VS ribozyme by NMR spectroscopy, the structure of the II-III-VI junction allows us to gain further insights into the overall three-dimensional structure of the complete VS ribozyme.

\section{The NMR structure of the II-III-VI junction core is consistent with biochemical data}

The core of the J236 RNA relies on a compact network of interactions (Figs. 3-5) that is compatible with previous mutagenesis studies of the VS ribozyme (Beattie et al. 1995; Lafontaine et al. 2001a; McLeod and Lilley 2004). In agreement with the structural importance of the cis WC/WC $\mathrm{A}_{10} \cdot \mathrm{G}_{53}$ base pair, single base substitutions of either $A_{10}$ or $G_{53}$, but not the $A_{10} \cdot G_{53}$ base pair inversion, greatly decrease (up to 500 -fold) the catalytic activity of the VS ribozyme (for simplicity, J236 numbering is used for VS ribozyme residues) (Lafontaine et al. 2001a; McLeod and Lilley 2004). Similarly, single base substitutions of either $A_{51}$ or $A_{52}$ within the $\mathrm{A}_{49} \mathrm{C}_{50} \mathrm{~A}_{51} \mathrm{~A}_{52}$ turn lead to reduction in cleavage activity $(\sim 20$-fold $)$, consistent with the participation of both $A_{51}$ and $\mathrm{A}_{52}$ in base triples (Fig. 5; Lafontaine et al. 2001a). In addition, single inversions of the junction proximal base pairs $\left(\mathrm{G}_{9}-\mathrm{C}_{54}\right.$ in stem II, $\mathrm{C}_{12}-\mathrm{G}_{28}$ and $\mathrm{U}_{13}-\mathrm{A}_{27}$ in stem III or $\mathrm{G}_{29}-\mathrm{C}_{48}$ in stem VI) did not significantly alter VS ribozyme catalytic activity (Beattie et al. 1995; Lafontaine et al. 2001a), which is consistent with the lack of tertiary interaction involving the closing base pairs of stems II and VI. Moreover, it suggests that the inversions of the $\mathrm{C}_{12}-\mathrm{G}_{28}$ and $\mathrm{U}_{13}-\mathrm{A}_{27}$ base pairs in stem III also support the formation of base triples equivalent to the $\left(\mathrm{U}_{13}-\mathrm{A}_{27}\right) \cdot \mathrm{A}_{51}$ and $\left(\mathrm{C}_{12}-\mathrm{G}_{28}\right) \cdot \mathrm{A}_{52}$ base triples. Using WebFR3D, we identified several examples in the PDB of such inverted $(\mathrm{A}-\mathrm{U}) \cdot \mathrm{A}$ and $(\mathrm{G}-\mathrm{C}) \cdot \mathrm{A}$ base triples with the same topology as those observed in J236 (Petrov et al. 2011).

Chemical probing data obtained under native conditions are also consistent with the J236 core structure. Briefly, the 


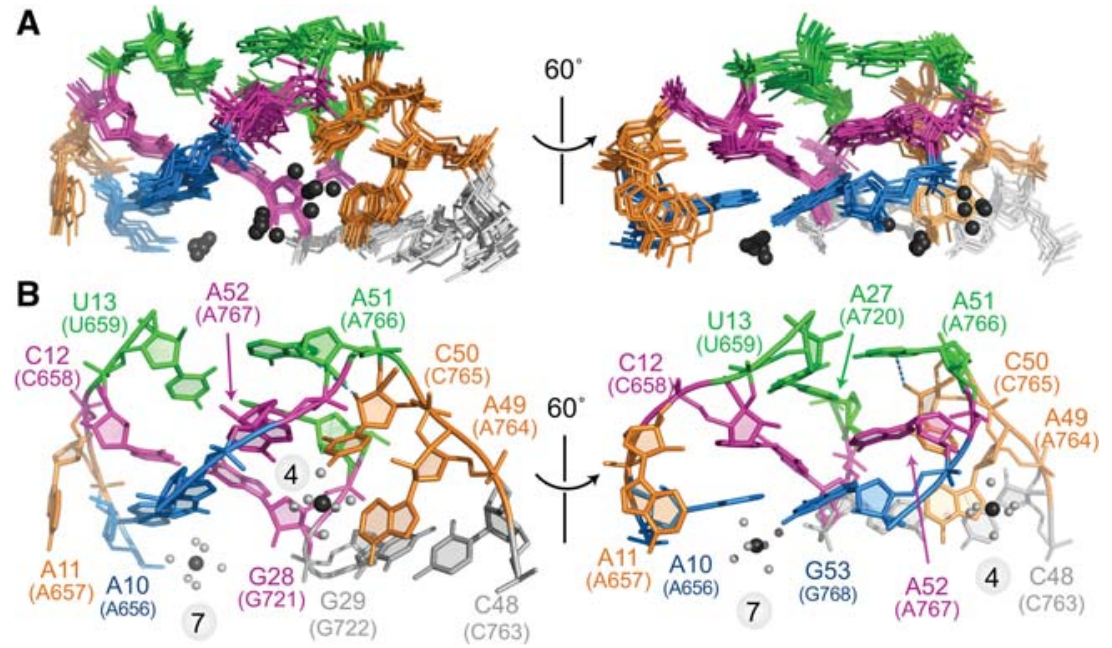

FIGURE 4. NMR structure of the core domain of $J 236^{\mathrm{Mg}}$. (A) Superposition of the 10 lowestenergy structures. Only heavy atoms of core residues $(10-13,27-29,48-53)$ are included in the superposition. The $\mathrm{Mg}^{2+}$ ions associated with each structure are shown as dark gray spheres. (B) Stick representations of the lowest-energy structure of the core domain. The $\mathrm{Mg}^{2+}$ ions at Sites 4 and 7 are shown in dark gray, with their bound water molecules in lighter gray. The cyan dashed line represents a hydrogen bond defined on the basis of a short distance $(\leq 4.0 \AA)$ between $C_{50}$ $2^{\prime}-\mathrm{OH}$ and $\mathrm{A}_{51} \mathrm{~N} 7$ in the ensemble of structures.

WC edges of all core residues are protected from chemical probing in the presence of $\mathrm{Mg}^{2+}$ ions, with the exception of $\mathrm{A}_{11}$ and $\mathrm{C}_{50}$, in agreement with the compact structure of the core (Beattie et al. 1995; Maguire and Collins 2001; Sood and Collins 2002). Similarly, the $5^{\prime}$-phosphates of $A_{10}, A_{11}$, and $G_{29}$ are protected from ethylnitrosourea (ENU) modification (Sood et al. 1998) and the riboses of $A_{10}, A_{27}, G_{28}$, and $G_{29}$ are protected from hydroxyl radical footprinting (Hiley and Collins 2001), in agreement with backbone distortion near these residues, reduced accessibility of ribose $\mathrm{C}^{\prime}$ within base triples (for $\mathrm{A}_{27}$ and $\mathrm{G}_{28}$; Fig. 5) and binding of a $\mathrm{Mg}^{2+}$ ion at Site 7 (for $\mathrm{A}_{10}$ and $\mathrm{G}_{29}$; Fig. 4). Moreover, the effect of chemical modifications on the VS ribozyme activity is consistent with the impairment of critical interactions observed in the NMR structure (Beattie and Collins 1997; Sood et al. 2002). Thus, the NMR structure of the J236 core is in general agreement with the available biochemical data for the VS ribozyme, indicating that the II-III-VI junction adopts a similar core structure within the active VS ribozyme.

As an exception, $A_{11}$ adopts a bulged out position in the NMR structure (Fig. 4) that appears incompatible with biochemical data. Substitution of this base by a U leads to a 15 -fold reduction in the cleavage activity (Lafontaine et al. 2001a), and this is similar to the effects of carboxyethylation at the N7 position (Beattie and Collins 1997) and base substitution by purine (Jones and Strobel 2003). Taken together, these results suggest that these modifications of $A_{11}$ prevent the formation of a tertiary interaction that is not present in J236 but may contribute to the cleavage activity of the VS ribozyme.

\section{The II-VI bulge-bulge interaction is supported by biochemical data}

The NMR structure of J236 reveals a bulge-bulge interaction between stems II and VI (Fig. 6). Interestingly, such remote tertiary interaction between two stems of a three-way junction is found in almost all junctions with family $\mathrm{C}$ topology (Lescoute and Westhof 2006; de la Pena et al. 2009). The one observed in J236 was not previously identified in the VS ribozyme, but is nevertheless consistent with previous mutagenesis data. In particular, it was demonstrated that the adenine bulges in stems II $\left(\mathrm{A}_{6}\right)$ and VI $\left(\mathrm{A}_{32} \mathrm{~A}_{33}\right)$ play critical roles in the VS ribozyme, since their deletion or strand inversion reduces the cleavage activity by up to 1000 -fold (Lafontaine et al. 2001b; Sood and Collins 2002; McLeod and Lilley 2004). Conversely, most single base substitutions of $\mathrm{A}_{6}, \mathrm{~A}_{32}$, and $\mathrm{A}_{33}$ do not significantly affect the cleavage
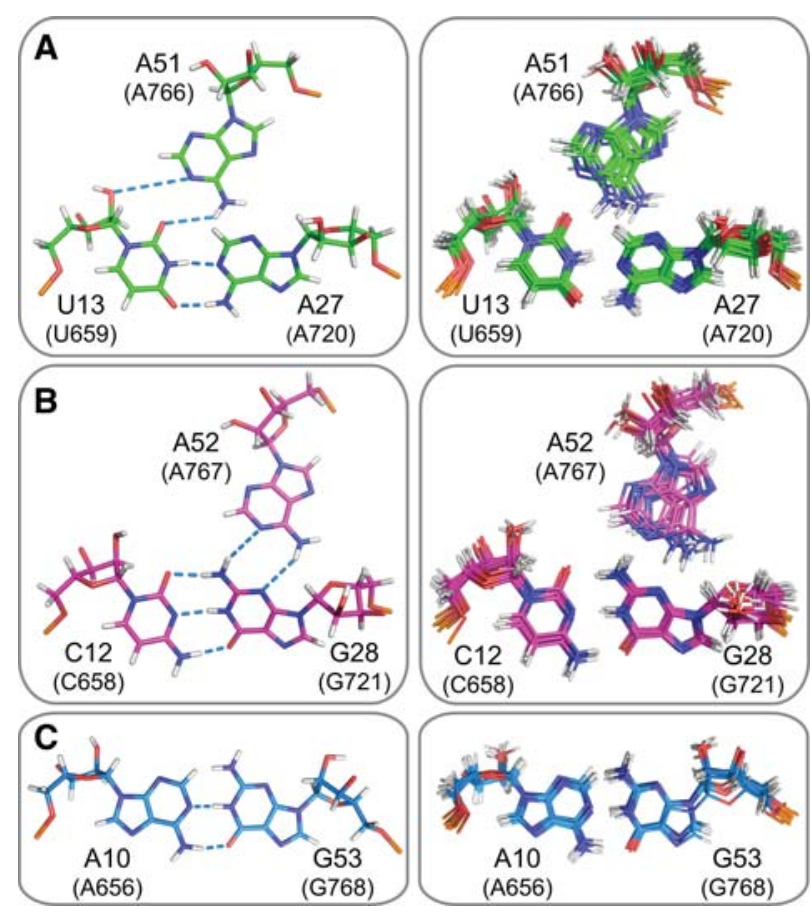

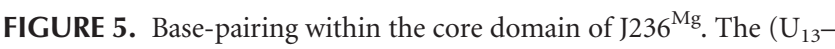
$\left.A_{27}\right) \cdot A_{51}$ minor groove base triple $(A)$, the $\left(C_{12}-G_{28}\right) \cdot A_{52}$ minor groove base triple $(B)$, and the cis WC/WC $\mathrm{A}_{10}{ }^{\circ} \mathrm{G}_{53}$ base pair $(C)$ located in the core of $J 236^{\mathrm{Mg}}$ are shown on the lowest-energy structure (left panels) and on the superposition of the 10 lowest-energy structures (right panels; only the residues shown were used for the superposition). Cyan dashed lines represent hydrogen bonds that are defined on the basis of short distances $(\leq 4.0 \AA)$ between heavy atoms in the ensemble of structures. 

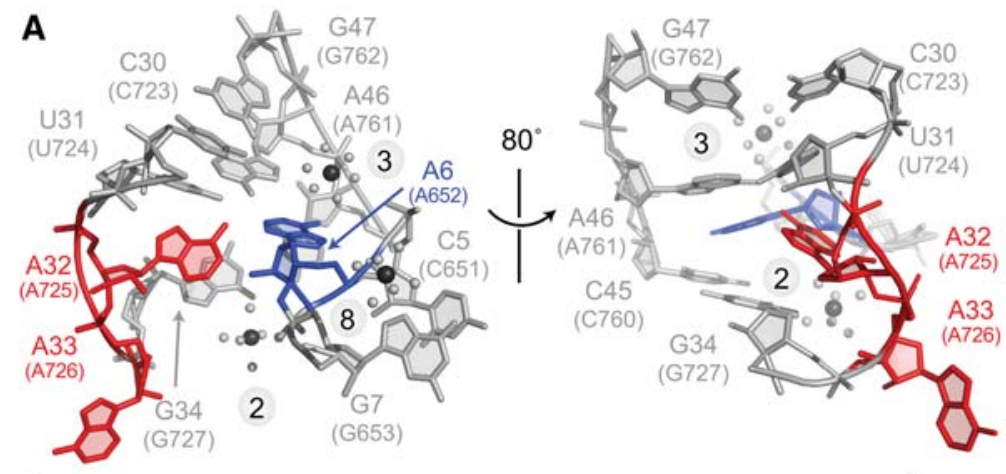

B
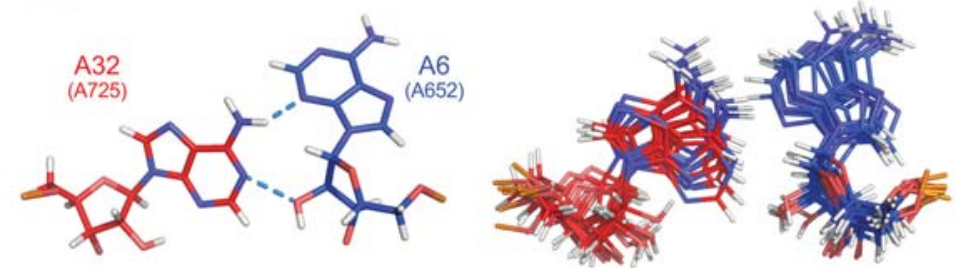

C

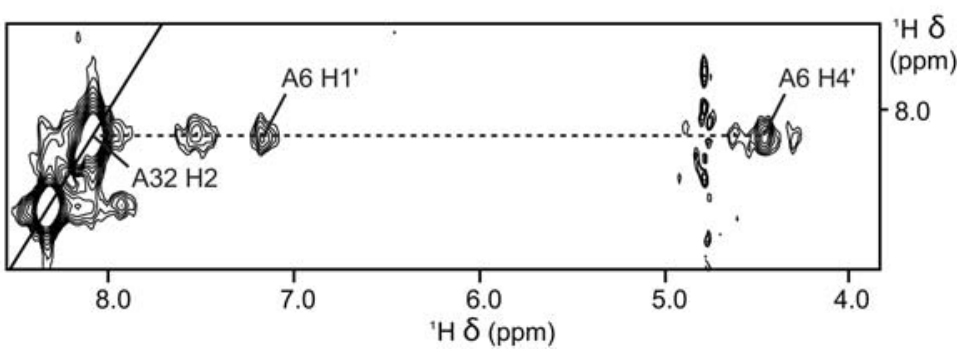

FIGURE 6. NMR structure of the II-VI bulge-bulge interaction of the J236 ${ }^{\mathrm{Mg}}$ RNA. (A) Stick representations of one of the lowest-energy structures of the II-VI bulge-bulge interaction showing the $\mathrm{A}_{6} \cdot \mathrm{A}_{32}$ base pair (left panel) and the S-turn at the $\mathrm{A}_{32} \mathrm{~A}_{33}$ bulge (right panel). Only heavy atoms from the bulges, the closing base pairs of stems II and VI and the S-turn at the $\mathrm{A}_{32} \mathrm{~A}_{33}$ bulge (residues 5-7, 30-34, 45-47), are shown. The $\mathrm{Mg}^{2+}$ ions at Sites 2, 3, and 8 are shown as dark gray spheres, with their bound water molecules in lighter gray. $(B)$ The cis Sugar edge/WC $\mathrm{A}_{6} \cdot \mathrm{A}_{32}$ base pair is shown from one of the lowest-energy structures (left panel) and on the superposition of the 10 lowest-energy structures (right panel; only the residues shown were used for the superposition). Cyan dashed lines represent hydrogen bonds that are defined on the basis of short distances $(\leq 4.0 \AA)$ between heavy atoms in the ensemble of structures. $(C)$ NMR evidence of the cis Sugar edge/WC $\mathrm{A}_{6} \cdot \mathrm{A}_{32}$ base pair provided by NOE signals between $\mathrm{A}_{6}$ and $\mathrm{A}_{32}$ protons. These NOEs are observed in the $2 \mathrm{D}{ }^{1} \mathrm{H}-{ }^{1} \mathrm{H}$ slice of a $3 \mathrm{D}{ }^{13} \mathrm{C}$-edited HMQC-NOESY spectrum $\left(\tau_{\mathrm{m}}=100 \mathrm{msec}\right)$ taken at the ${ }^{13} \mathrm{C}$ chemical shifts of $\mathrm{A}_{32} \mathrm{C} 2(156.3 \mathrm{ppm})$. The dotted line is drawn at the ${ }^{1} \mathrm{H}$ chemical shift of $\mathrm{A}_{32} \mathrm{H} 2$ (8.08 ppm).

activity (Lafontaine et al. 2001b; Sood and Collins 2002). These results are in agreement with the bulged out position of $\mathrm{A}_{33}$ and a large subset of isosteric base pairs for the cis Sugar edge/WC $\mathrm{A}_{6} \cdot \mathrm{A}_{32}$ base pair (Fig. 6; Leontis et al. 2002).

The II-VI bulge-bulge interaction is also supported by both chemical probing and interference data. In chemical probing experiments performed under native conditions, the WC and Hoogsteen edges of both $\mathrm{A}_{6}$ and $\mathrm{A}_{32}$ but not $\mathrm{A}_{33}$ are protected from chemical modifications, consistent with the cis Sugar edge/WC $\mathrm{A}_{6} \cdot \mathrm{A}_{32}$ base pair being nested between the minor grooves of stems II and VI and the exclusion of $\mathrm{A}_{33}$ within the S-turn (Fig. 6; Beattie et al. 1995; Maguire and Collins 2001; Sood and Collins 2002). In addition, the 5'phosphates of $\mathrm{G}_{7}$ and $\mathrm{G}_{34}$ are protected from modification by ENU and phosphorothioate substitution of $\mathrm{G}_{7}$ interferes with the cleavage activity, in agreement with the $5^{\prime}$-phosphates of $G_{7}$ and $G_{34}$ contributing to electrostatic stabilization of the $\mathrm{Mg}^{2+}$ ion at Site 2 (Fig. 6; Table 2; Sood et al. 1998). Furthermore, a UV-inducible crosslink was reported between $\mathrm{A}_{6}$ and $A_{46}$ (Sood and Collins 2002), in accordance with these residues being stacked on each other (Fig. 6A). Hence, the II-VI bulge-bulge interaction revealed by the NMR structure of J236 correlates very well with previously published biochemical data and most likely adopts an equivalent structure in the active VS ribozyme.

\section{The structure of the II-III-VI junction depends on the II-VI bulge-bulge interaction and the binding of $\mathrm{Mg}^{2+}$ ions}

Although different topologies and helical stacking schemes have been predicted for the VS ribozyme II-III-VI junction (Lescoute and Westhof 2006; Tyagi and Mathews 2007; Laing et al. 2012), the NMR structure of J236 establishes that it adopts a single conformation with a family C topology and continuous helical stacking of stems II and III. Such helical stacking was not observed in a similar three-way junction from rRNA, and this may explain the 10-fold lower activity of a hybrid VS ribozyme in which the core of the II-III-VI junction was replaced by this rRNA three-way junction (Lafontaine et al. 2001a; Lipfert et al. 2008). Similarly, continuous stacking between stems II and III is not compatible with comparative gel electrophoresis and FRET studies of the II-III-VI junction (Lafontaine et al. 2001a), which rather suggested near-coaxial alignment of stems III and VI. However, in these studies, a minimal IIIII-VI junction was used that did not allow for formation of the II-VI bulge-bulge interaction. Correspondingly, we observe that J236 variants in which the II-VI bulge-bulge interaction is impaired do not adopt a stable structure.

The overall fold of the II-III-VI junction also depends on the presence of $\mathrm{Mg}^{2+}$ ions. Our NMR data indicate that the junction core and the II-VI bulge-bulge interaction are both destabilized in the absence of $\mathrm{Mg}^{2+}$ ions. In addition, they provide evidence for binding of two $\mathrm{Mg}^{2+}$ ions in the J236 core and three $\mathrm{Mg}^{2+}$ ions within the II-VI bulge-bulge interaction. Notably, the $\mathrm{Mg}^{2+}$ ions at Sites 2, 3, and 8 within these two substructures help bridge phosphates that are 
remote in the primary structure. In agreement with a $\mathrm{Mg}^{2+}$-dependent structure for the II-III-VI junction, the Hoogsteen and WC edges of several purines, including $\mathrm{A}_{6}$ and $\mathrm{A}_{32}$ of the bulges, are more protected from chemical modification in the presence of $\mathrm{Mg}^{2+}$ ions (Beattie et al. 1995; Beattie and Collins 1997). Moreover, the critical role of $\mathrm{Mg}^{2+}$ ions in stabilizing the II-III-VI junction is supported by a single-molecule FRET study of the VS ribozyme that revealed important conformational changes induced by $\mathrm{Mg}^{2+}$ ions (Pereira et al. 2008).

\section{Novel insights into the global structure of the VS ribozyme}

NMR structures of several isolated subdomains of the Neurospora VS ribozyme have been previously determined, and with the NMR structure of the II-III-VI junction presented here, all nonhelical domains of the minimal VS ribozyme are now structurally characterized. Based on these NMR structures, we drew a structural schematic and built a three-dimensional model of a trans ribozyme/substrate complex that provide significant insights into the global organization of the complete VS ribozyme (Fig. 7). In particular, the two three-way junctions both adopt a family $\mathrm{C}$ topology that clearly defines the orientation of their attached stems. In the II-III-VI three-way junction, stem III directly stacks on stem II and an ACAA turn connects stems II and VI.
Similarly, we previously found that in the III-IV-V threeway junction, stem IV directly stacks on stem III and a Uturn connects stems III and V (Bonneau and Legault 2014 b). Thus, these two junctions must allow stacking of stems II, III, and IV to create an extended, continuous helical segment from which stems V and VI project alongside stems III and II, respectively. The SLI substrate associates with the trans VS ribozyme via the $\mathrm{I} / \mathrm{V}$ kissing-loop interaction (Lacroix-Labonté et al. 2012), and this interaction creates a more or less continuous helical region encompassing SLV and SLI (Bouchard and Legault 2014b). In the three-dimensional model, the cleavage site internal loop of SLI is not docked with SLVI to create the active site. Instead, it adopts an open state that is compatible with the ground-state conformation characterized by chemical probing and biophysical studies (Hiley et al. 2002; Pereira et al. 2008; Desjardins et al. 2011; Bouchard and Legault 2014a). Future work should focus on refining this NMR-based model of the Neurospora VS ribozyme using global structural restraints and characterizing the dynamics that allow formation of the catalytically active docked structure.

\section{MATERIALS AND METHODS}

\section{Plasmids}

Double-stranded PCR fragments coding for the J236-VS, J236- $\mathrm{A}_{6}$ bp-VS, and J236- $\Delta \mathrm{A}_{6}$-VS RNAs and flanked by a T7 promoter,

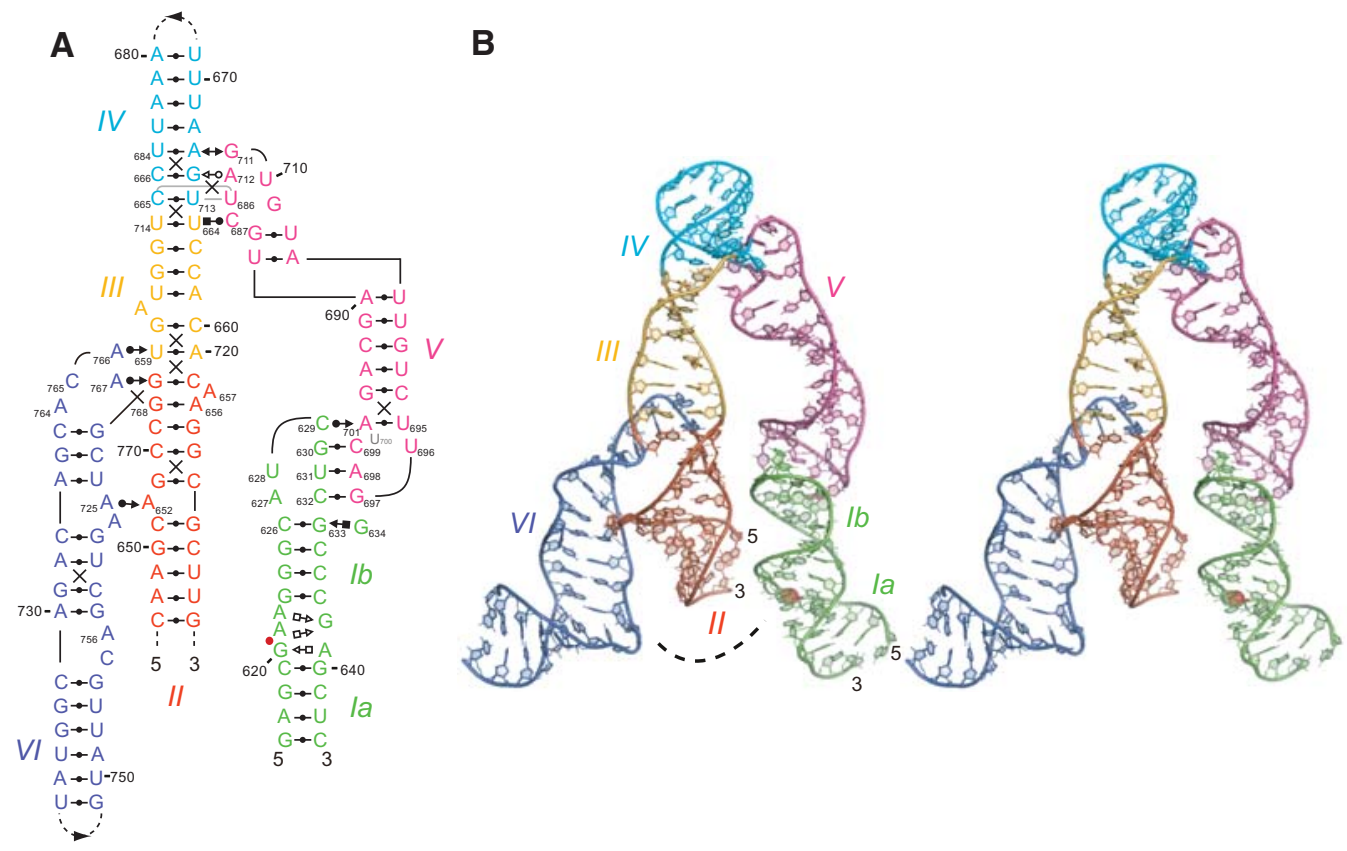

FIGURE 7. Overview of the tertiary structure of the complete VS ribozyme based on NMR structures of isolated subdomains. (A) Schematic of the tertiary structure of a trans VS ribozyme and bound substrate based on the $S_{0} / R_{0}$ system (Lacroix-Labonté et al. 2012). Canonical and noncanonical base pairs are represented using the Leontis-Westhof notation, except for the $\mathrm{C}_{665} \cdot \mathrm{U}_{713} \cdot \mathrm{U}_{686}$ base triple where intermediate interactions were represented by gray lines (Leontis and Westhof 2001; Abu Almakarem et al. 2012). (B) Stereoview of the NMR-based model of a substrate/ribozyme complex in an open conformation. Due to the modeling approach, this complex differs slightly from the $S_{0} / R_{0}$ complex (see text). The cleavage site (small red sphere) must form an interaction with the A730 loop (dashed line) to form the active site. The color-coding of the helical segments is equivalent in $A$ and $B$. 
were inserted into the HindIII/EcoRI sites of the pTZ19R-derived pTR-4 vector (Rastogi and Collins 1998) to generate the pJ236, pJ236- $\Delta \mathrm{A}_{6}$, and pJ236- $\mathrm{A}_{6}$-bp plasmids. These plasmids were fully linearized using EcoRI (New England Biolabs) and used for tran-

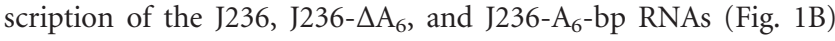
with a VS ribozyme substrate at their $3^{\prime}$ end (Rastogi and Collins 1998).

\section{RNA synthesis and purification}

Unlabeled, ${ }^{15} \mathrm{~N}$-labeled and ${ }^{13} \mathrm{C} /{ }^{15} \mathrm{~N}$-labeled RNAs (J236-VS, J236$\Delta \mathrm{A}_{6}$-VS, and J236- $\mathrm{A}_{6}$-bp-VS) were synthesized in vitro with the T7 RNA polymerase, as previously described (Bonneau and Legault 2014b). Nucleotide-specific ${ }^{13} \mathrm{C} /{ }^{15} \mathrm{~N}$-labeled J236-VS RNAs were also synthesized using purified ${ }^{13} \mathrm{C} /{ }^{15} \mathrm{~N}$ ATP, ${ }^{13} \mathrm{C} /{ }^{15} \mathrm{~N}$ CTP, or ${ }^{13} \mathrm{C} /{ }^{15} \mathrm{~N}$ GTP for preparation of $\mathrm{A}^{\mathrm{CN}}-\mathrm{J} 236, \mathrm{C}^{\mathrm{CN}}-\mathrm{J} 236$, and $\mathrm{G}^{\mathrm{CN}}$ J236 RNAs (Dagenais and Legault 2012). Following RNA synthesis, the VS ribozyme substrate was cleaved using a trans-acting VS ribozyme to produce a homogeneous $3^{\prime}$ end (Guo and Collins 1995; Rastogi and Collins 1998). The RNAs were then purified by denaturing gel electrophoresis, treated with calf intestinal alkaline phosphatase (CIP, Roche Diagnostics) to remove their $5^{\prime}$-phosphates, and further purified by DEAE-Sepharose chromatography (Delfosse et al. 2010; Bonneau and Legault 2014a). The purified RNAs were concentrated and exchanged in NMR buffer A $(10 \mathrm{mM}$ sodium cacodylate [pH 6.5], $50 \mathrm{mM} \mathrm{KCl}, 0.05 \mathrm{mM} \mathrm{NaN}_{3}$ and 90\%:10\% $\mathrm{H}_{2} \mathrm{O}: \mathrm{D}_{2} \mathrm{O}$ ) with Amicon Ultra-4 centrifugation filter devices (Millipore). The RNAs were then heated at $37^{\circ} \mathrm{C}$ for $2 \mathrm{~min}$ and cooled in ice water for 5 min before changing to the final NMR buffer using the same filter device (NMR buffer A with $5 \mathrm{mM} \mathrm{MgCl}_{2} 99.995 \%$ [Sigma-Aldrich]). For NMR studies in $\mathrm{D}_{2} \mathrm{O}$, the samples were obtained by four cycles of lyophilization and resuspension in $99.996 \% \mathrm{D}_{2} \mathrm{O}$.

\section{NMR spectroscopy}

All NMR experiments were collected on a Varian Unity INOVA 600 $\mathrm{MHz}$ spectrometer. NMR resonance assignment and structural restraints for the J236 RNA were obtained as previously described (Bonneau and Legault 2014b). In addition, an A-specific H(NC)TOCSY-(C)H spectrum (Simorre et al. 1996) was collected for unambiguous assignment of the adenine protons in the junction. It is important to note that 3D CT-HCCH-COSY (Pardi and Nikonowicz 1992), 3D HCCH-TOCSY (Pardi and Nikonowicz 1992), and ${ }^{13} \mathrm{C}$-edited HMQC-NOESY (Ikura et al. 1990) spectra collected on nucleotide-specific ${ }^{13} \mathrm{C} /{ }^{15} \mathrm{~N}$-labeled J236 RNAs $\left(\mathrm{A}^{\mathrm{CN}}\right.$ J236, $\mathrm{C}^{\mathrm{CN}}-\mathrm{J} 236$, and $\mathrm{G}^{\mathrm{CN}}-\mathrm{J} 236$ RNAs) significantly contributed to the unambiguous assignment of NMR signals from the fully ${ }^{13} \mathrm{C} /{ }^{15} \mathrm{~N}$-labeled J236. NOE-derived distance restraints were separated in four classes based on NOE crosspeak intensities, and dihedral angle restraints for the sugar puckers $(\delta)$ and other backbone dihedral angles $(\alpha, \gamma, \chi$, and $\zeta)$ were defined based on comparative NOE analyses (Wijmenga et al. 1993). Canonical distance restraints and backbone torsion angles were used to define helical regions in agreement with the NMR data. NMR chemical shifts, structural restraints and structural coordinates have been deposited for J236 and $\mathrm{J} 236^{\mathrm{Mg}}$ as BMRB accession numbers 25654 and 25655 and PDB ID codes $2 \mathrm{~N} 3 \mathrm{Q}$ and $2 \mathrm{~N} 3 \mathrm{R}$, respectively.

\section{Metal-ion binding studies}

Manganese $\left(\mathrm{Mn}^{2+}\right)$ titrations were performed with two J236 samples (1.5-mM ${ }^{15} \mathrm{~N}$-labeled $\mathrm{J} 236$ and $2.0-\mathrm{mM}{ }^{13} \mathrm{C} /{ }^{15} \mathrm{~N}$-labeled J236) in NMR buffer A containing $5 \mathrm{mM} \mathrm{MgCl}_{2}$, as previously described (Bonneau and Legault 2014a). RNA-metal distance restraints were derived from $\mathrm{Mn}^{2+}$-induced paramagnetic relaxation enhancement (PRE) using the ratio of signal intensity $\left(I_{\mathrm{o}} / I_{\mathrm{Mn}}\right)$ determined from spectra collected with $\left(I_{\mathrm{Mn}}\right)$ and without $\left(I_{\mathrm{o}}\right)$ $20 \mu \mathrm{M} \mathrm{MnCl}_{2}$ (Bonneau and Legault 2014a).

\section{Structure calculation}

Three-dimensional structures of J236 were calculated using restrained molecular dynamics and simulated annealing in X-PLOR-NIH version 2.1.9 (Schwieters et al. 2003) starting from structures with randomized backbone angles, as previously described (Campbell et al. 2006). A force field was used that included bond, angle, improper and repulsive van der Waals energy terms as well as NOE and torsion-angle pseudoenergy terms, but no electrostatic terms. Three-dimensional structures of J236 bound to eight magnesium complexes $\left[\mathrm{Mg}\left(\mathrm{H}_{2} \mathrm{O}\right)_{6}^{2+}\right]$ (Kleywegt and Jones 1998) termed $\mathrm{J}_{236^{\mathrm{Mg}}}$, were calculated as described for J236, but using additional metal-RNA restraints (Bonneau and Legault 2014a). For both $\mathrm{J} 236$ and $\mathrm{J} 236^{\mathrm{Mg}}$, the 20 lowest-energy structures that satisfied all the experimental restraints (all distance violations $<0.2 \AA$ and all torsion-angle violations $<5^{\circ}$ ) were selected for anal$y$ sis and used to calculate average structures that were minimized against all experimental restraints. Structures were visualized with PyMOL Molecular Graphics System, Version 1.3 Schrödinger, and analyzed with PyMOL and Curves+ (Lavery et al. 2009). Reported values of RMSD, interatomic distances and interhelical angles are given as average values with standard deviations for the 20 lowest-energy structures. To calculate the interhelical angles, the helical segments were defined as residues 7-10 and 53-56 for stem II, residues $12-14$ and 26-28 for stem III and residues $29-31$ and 46-48 for stem VI.

\section{Three-dimensional modeling of the complete ribozyme}

A three-dimensional model of a VS ribozyme substrate/ribozyme complex (Fig. 7A; Lacroix-Labonté et al. 2012) was generated by assembly of NMR structures of individual subdomains in PyMOL based on superposition of overlapping helical segments. The following NMR structures of isolated subdomains were used: the cleavage site internal loop of the SLI substrate in its active form (PDB ID code 1OW9) (Hoffmann et al. 2003), the terminal loop of SLV in the presence of $\mathrm{Mg}^{2+}$ (PDB ID code 1YN1) (Campbell et al. 2006), the I/V kissing-loop interaction (PDB ID code 2MI0) (Bouchard and Legault 2014b), the A730 loop of SLVI (PDB ID code 2L5Z) (Desjardins et al. 2011), the III-IV-V junction (PDB ID code 2MTJ) (Bonneau and Legault 2014b) and the II-III-VI junction (PDB ID code $2 \mathrm{~N} 3 \mathrm{Q}$ ). The initial model was then minimized with the molecular dynamics package GROMACS (Pronk et al. 2013) and the Amber99SB force field with the ParmBSC0 nucleic acid parameters and using explicit aqueous solvent (Hornak et al. 2006; Perez et al. 2007; Guy et al. 2012). 


\section{ACKNOWLEDGMENTS}

We thank Aurélie Tréfier and Dominique Chaussé for their help with sample preparation, Ryan Richter for computer support, as well as Pierre Dagenais and James G. Omichinski for discussions and critical reading of the manuscript. We also thank Calcul Québec for providing computing facilities. This work was supported by a Canadian Institutes of Health Research (CIHR) grant to P.L. (MOP-86502). E.B. was supported by a Frederick Banting and Charles Best Canada Graduate Scholarship PhD scholarship from CIHR and graduate scholarships from the Université de Montréal. P.L. holds a Canada Research Chair in Structural Biology and Engineering of RNA. Funding for open access charge was provided by CIHR.

Received March 31, 2015; accepted June 8, 2015.

\section{REFERENCES}

Abu Almakarem AS, Petrov AI, Stombaugh J, Zirbel CL, Leontis NB. 2012. Comprehensive survey and geometric classification of base triples in RNA structures. Nucleic Acids Res 40: 1407-1423.

Andersen AA, Collins RA. 2000. Rearrangement of a stable RNA secondary structure during VS ribozyme catalysis. Mol Cell 5: 469478.

Andersen AA, Collins RA. 2001. Intramolecular secondary structure rearrangement by the kissing interaction of the Neurospora VS ribozyme. Proc Natl Acad Sci 98: 7730-7735.

Beattie TL, Collins RA. 1997. Identification of functional domains in the self-cleaving Neurospora VS ribozyme using damage selection. J Mol Biol 267: 830-840.

Beattie TL, Olive JE, Collins RA. 1995. A secondary-structure model for the self-cleaving region of Neurospora VS RNA. Proc Natl Acad Sci 92: 4686-4690.

Bonneau E, Legault P. 2014a. NMR localization of divalent cations at the active site of the Neurospora VS ribozyme provides insights into RNA-metal-ion interactions. Biochemistry 53: 579-590.

Bonneau E, Legault P. 2014b. Nuclear magnetic resonance structure of the III-IV-V three-way junction from the Varkud Satellite ribozyme and identification of magnesium-binding sites using paramagnetic relaxation enhancement. Biochemistry 53: 6264-6275.

Bouchard P, Legault P. 2014a. A remarkably stable kissing-loop interaction defines substrate recognition by the Neurospora VS Ribozyme. RNA 20: 1451-1464.

Bouchard P, Legault P. 2014b. Structural insights into substrate recognition by the Neurospora Varkud satellite ribozyme: importance of U-turns at the kissing-loop junction. Biochemistry 53: 258-269.

Burke JE, Sashital DG, Zuo X, Wang YX, Butcher SE. 2012. Structure of the yeast U2/U6 snRNA complex. RNA 18: 673-683.

Campbell DO, Legault P. 2005. NMR structure of the Varkud satellite ribozyme stem-loop V RNA and magnesium-ion binding from chemical-shift mapping. Biochemistry 44: 4157-4170.

Campbell DO, Bouchard P, Desjardins G, Legault P. 2006. NMR structure of Varkud satellite ribozyme stem-loop V in the presence of magnesium ions and localization of metal-binding sites. Biochemistry 45: 10591-10605.

Cochrane JC, Strobel SA. 2008. Catalytic strategies of self-cleaving ribozymes. Acc Chem Res 41: 1027-1035.

Collins RA. 2002. The Neurospora Varkud satellite ribozyme. Biochem Soc Trans Rev 30: 1122-1126.

Collins RA, Olive JE. 1993. Reaction conditions and kinetics of selfcleavage of a ribozyme derived from Neurospora VS RNA. Biochemistry 32: 2795-2799.

Correll CC, Freeborn B, Moore PB, Steitz TA. 1997. Metals, motifs, and recognition in the crystal structure of a $5 \mathrm{~S}$ rRNA domain. Cell 91 : 705-712.
Dagenais P, Legault P. 2012. Preparative separation of ribonucleoside monophosphates by ion-pair reverse-phase HPLC. Methods Mol Biol 941: 247-256.

de la Pena M, Dufour D, Gallego J. 2009. Three-way RNA junctions with remote tertiary contacts: a recurrent and highly versatile fold. RNA 15: 1949-1964.

Delfosse V, Bouchard P, Bonneau E, Dagenais P, Lemay JF, Lafontaine DA, Legault P. 2010. Riboswitch structure: an internal residue mimicking the purine ligand. Nucleic Acids Res 38: 20572068.

Desjardins G, Bonneau E, Girard N, Boisbouvier J, Legault P. 2011. NMR structure of the A730 loop of the Neurospora VS ribozyme: insights into the formation of the active site. Nucleic Acids Res 39: 4427-4437.

D'Souza V, Dey A, Habib D, Summers MF. 2004. NMR structure of the 101-nucleotide core encapsidation signal of the Moloney murine leukemia virus. J Mol Biol 337: 427-442.

Flinders J, Dieckmann T. 2001. A pH controlled conformational switch in the cleavage site of the VS ribozyme substrate RNA. J Mol Biol 308: 665-679.

Flinders J, Dieckmann T. 2004. The solution structure of the VS ribozyme active site loop reveals a dynamic "hot-spot". J Mol Biol 341: 935-949.

Guo HCT, Collins RA. 1995. Efficient trans-cleavage of a stem-loop RNA substrate by a ribozyme derived from Neurospora VS RNA. EMBO J 14: 368-376.

Guy AT, Piggot TJ, Khalid S. 2012. Single-stranded DNA within nanopores: conformational dynamics and implications for sequencing; a molecular dynamics simulation study. Biophys J 103: 1028-1036.

Hiley SL, Collins RA. 2001. Rapid formation of a solvent-inaccessible core in the Neurospora Varkud satellite ribozyme. EMBO J 20: 5461-5469.

Hiley SL, Sood VD, Fan J, Collins RA. 2002. 4-Thio-U cross-linking identifies the active site of the VS ribozyme. EMBO J 21: 4691-4698.

Hoffmann B, Mitchell GT, Gendron P, Major F, Andersen AA, Collins RA, Legault P. 2003. NMR structure of the active conformation of the Varkud satellite ribozyme cleavage site. Proc Natl Acad Sci 100: 7003-7008.

Hornak V, Abel R, Okur A, Strockbine B, Roitberg A, Simmerling C. 2006. Comparison of multiple Amber force fields and development of improved protein backbone parameters. Proteins 65: 712-725.

Ikura M, Kay LE, Tschudin R, Bax A. 1990. Three-dimensional NOESYHMQC spectroscopy of a ${ }^{13} \mathrm{C}$-labeled protein. J Magn Reson 86: 204-209.

Jaikaran D, Smith MD, Mehdizadeh R, Olive J, Collins RA. 2008. An important role of G638 in the cis-cleavage reaction of the Neurospora VS ribozyme revealed by a novel nucleotide analog incorporation method. RNA 14: 938-949.

Jones FD, Strobel SA. 2003. Ionization of a critical adenosine residue in the Neurospora Varkud satellite ribozyme active site. Biochemistry 42: $4265-4276$.

Keane SC, Heng X, Lu K, Kharytonchyk S, Ramakrishnan V, Carter G, Barton S, Hosic A, Florwick A, Santos J, et al. 2015. RNA structure. Structure of the HIV-1 RNA packaging signal. Science 348: 917-921.

Kleywegt GT, Jones TA. 1998. Databases in protein crystallography. Acta Crystallogr D Biol Crystallogr 54: 1119-1131.

Lacroix-Labonté J, Girard N, Lemieux S, Legault P. 2012. Helix-length compensation studies reveal the adaptability of the VS ribozyme architecture. Nucleic Acids Res 40: 2284-2293.

Lafontaine DA, Norman DG, Lilley DM. 2001a. Structure, folding and activity of the VS ribozyme: importance of the 2-3-6 helical junction. EMBO J 20: 1415-1424.

Lafontaine DA, Wilson TJ, Norman DG, Lilley DM. 2001b. The A730 loop is an important component of the active site of the VS ribozyme. J Mol Biol 312: 663-674.

Lafontaine DA, Norman DG, Lilley DM. 2002. The global structure of the VS ribozyme. EMBO J. 21: 2461-2471.

Laing C, Wen D, Wang JT, Schlick T. 2012. Predicting coaxial helical stacking in RNA junctions. Nucleic Acids Res 40: 487-498. 
Lambert D, Heckman JE, Burke JM. 2006. Three conserved guanosines approach the reaction site in native and minimal hammerhead ribozymes. Biochemistry 45: 7140-7147.

Lavery R, Moakher M, Maddocks JH, Petkeviciute D, Zakrzewska K. 2009. Conformational analysis of nucleic acids revisited: curves+. Nucleic Acids Res 37: 5917-5929.

Leontis NB, Westhof E. 2001. Geometric nomenclature and classification of RNA base pairs. RNA 7: 499-512.

Leontis NB, Stombaugh J, Westhof E. 2002. The non-Watson-Crick base pairs and their associated isostericity matrices. Nucleic Acids Res 30: 3497-3531.

Lescoute A, Westhof E. 2006. Topology of three-way junctions in folded RNAs. RNA 12: 83-93.

Lilley DM. 2004. The Varkud satellite ribozyme. RNA 10: 151-158.

Lilley DMJ. 2008. The hairpin and Varkud satellite ribozymes. In Ribozymes and RNA catalysis (ed. Lilley DMJ, Eckstein F), pp. 66-91. Royal Society of Chemistry, Cambridge.

Lipfert J, Ouellet J, Norman DG, Doniach S, Lilley DM. 2008. The complete VS ribozyme in solution studied by small-angle X-ray scattering. Structure 16: 1357-1367.

Lukavsky PJ, Kim I, Otto GA, Puglisi JD. 2003. Structure of HCV IRES domain II determined by NMR. Nat Struct Biol 10: 1033-1038.

Maguire JL, Collins RA. 2001. Effects of cobalt hexamine on folding and self-cleavage of the Neurospora VS ribozyme. J Mol Biol 309: 45-56.

McFail-Isom L, Shui X, Williams LD. 1998. Divalent cations stabilize unstacked conformations of DNA and RNA by interacting with base pi systems. Biochemistry 37: 17105-17111.

McLeod AC, Lilley DM. 2004. Efficient, pH-dependent RNA ligation by the VS ribozyme in trans. Biochemistry 43: 1118-1125.

Michiels PJ, Schouten CHJ, Hilbers CW, Heus HA. 2000. Structure of the ribozyme substrate hairpin of Neurospora VS RNA: a close look at the cleavage site. RNA 6: 1821-1832.

Miller SB, Yildiz FZ, Lo JA, Wang B, D’Souza VM. 2014. A structurebased mechanism for tRNA and retroviral RNA remodelling during primer annealing. Nature 7528: 591-595.

Miyazaki Y, Irobalieva RN, Tolbert BS, Smalls-Mantey A, Iyalla K, Loeliger K, D'Souza V, Khant H, Schmid MF, Garcia EL, et al. 2010. Structure of a conserved retroviral RNA packaging element by NMR spectroscopy and cryo-electron tomography. J Mol Biol 404: 751-772.

Murray JB, Seyhan AA, Walter NG, Burke JM, Scott WG. 1998. The hammerhead, hairpin and VS ribozymes are catalytically proficient in monovalent cations alone. Chem Biol 5: 587-595.

Pardi A, Nikonowicz EP. 1992. Simple procedure for resonance assignment of the sugar protons in ${ }^{13} \mathrm{C}-$ labeled RNAs. J Am Chem Soc 114: 9202-9203.

Pereira MJ, Nikolova EN, Hiley SL, Jaikaran D, Collins RA, Walter NG. 2008. Single VS ribozyme molecules reveal dynamic and hierarchical folding toward catalysis. J Mol Biol 382: 496-509.

Perez A, Marchan I, Svozil D, Sponer J, Cheatham TE III, Laughton CA, Orozco M. 2007. Refinement of the AMBER force field for nucleic acids: improving the description of $\alpha / \gamma$ conformers. Biophys J 92: 3817-3829.

Petrov AI, Zirbel CL, Leontis NB. 2011. WebFR3D-a server for finding, aligning and analyzing recurrent RNA 3D motifs. Nucleic Acids Res 39(Web Server issue): W50-W55.

Pronk S, Pall S, Schulz R, Larsson P, Bjelkmar P, Apostolov R, Shirts MR, Smith JC, Kasson PM, van der Spoel D, et al. 2013.
GROMACS 4.5: a high-throughput and highly parallel open source molecular simulation toolkit. Bioinformatics 29: 845-854.

Rastogi T, Collins RA. 1998. Smaller, faster ribozymes reveal the catalytic core of Neurospora VS RNA. J Mol Biol 277: 215-224.

Rastogi T, Beattie TL, Olive JE, Collins RA. 1996. A long-range pseudoknot is required for activity of the Neurospora VS ribozyme. EMBO J 15: $2820-2825$.

Roth A, Weinberg Z, Chen AG, Kim PB, Ames TD, Breaker RR. 2014. A widespread self-cleaving ribozyme class is revealed by bioinformatics. Nat Chem Biol 10: 56-60.

Saville BJ, Collins RA. 1990. A site-specific self-cleavage reaction performed by a novel RNA in Neurospora mitochondria. Cell 61: 685-696.

Saville BL, Collins RA. 1991. RNA-mediated ligation of self-cleavage products of a Neurospora mitochondrial plasmid transcript. Proc Natl Acad Sci 88: 8826-8830.

Schwieters CD, Kuszewski JJ, Tjandra N, Clore GM. 2003. The XplorNIH NMR molecular structure determination package. J Magn Reson 160: 66-74.

Simorre JP, Zimmermann GR, Mueller L, Pardi A. 1996. Triple-resonance experiments for assignment of adenine base resonances in ${ }^{13} \mathrm{C} /{ }^{15} \mathrm{~N}$-labeled RNA. J Am Chem Soc 118: 5316-5317.

Smith MD, Collins RA. 2007. Evidence for proton transfer in the ratelimiting step of a fast-cleaving Varkud satellite ribozyme. Proc Natl Acad Sci 104: 5818-5823.

Smith MD, Mehdizadeh R, Olive JE, Collins RA. 2008. The ionic environment determines ribozyme cleavage rate by modulation of nucleobase pKa. RNA 14: 1942-1949.

Sood VD, Collins RA. 2002. Identification of the catalytic subdomain of the VS ribozyme and evidence for remarkable sequence tolerance in the active site loop. J Mol Biol 320: 443-454.

Sood VD, Beattie TL, Collins RA. 1998. Identification of phosphate groups involved in metal binding and tertiary interactions in the core of the Neurospora VS ribozyme. J Mol Biol 282: 741-750.

Sood VD, Yekta S, Collins RA. 2002. The contribution of 2'-hydroxyls to the cleavage activity of the Neurospora VS ribozyme. Nucleic Acids Res 30: 1132-1138.

Tyagi R, Mathews DH. 2007. Predicting helical coaxial stacking in RNA multibranch loops. RNA 13: 939-951.

von Ahsen U, Green R, Schroeder R, Noller HF. 1997. Identification of 2 -hydroxyl groups required for interaction of a tRNA anticodon stem-loop region with the ribosome. RNA 3: 49-56.

Wijmenga SS, Mooren MMW, Hilbers CW. 1993. NMR of nucleic acids; from spectrum to structure. In NMR of macromolecules: a practical approach (ed. Roberts GCK), vol. 134, pp. 217-288. Oxford University Press, New York.

Wilson TJ, Lilley DM. 2011. Do the hairpin and VS ribozymes share a common catalytic mechanism based on general acid-base catalysis? A critical assessment of available experimental data. RNA 17: 213-221.

Wilson TJ, McLeod AC, Lilley DM. 2007. A guanine nucleobase important for catalysis by the VS ribozyme. EMBO J. 26: 2489-2500.

Wilson TJ, Li NS, Lu J, Frederiksen JK, Piccirilli JA, Lilley DM. 2010. Nucleobase-mediated general acid-base catalysis in the Varkud satellite ribozyme. Proc Natl Acad Sci 107: 11751-11756.

Zhao ZY, McLeod A, Harusawa S, Araki L, Yamaguchi M, Kurihara T, Lilley DM. 2005. Nucleobase participation in ribozyme catalysis. $J$ Am Chem Soc 127: 5026-5027. 

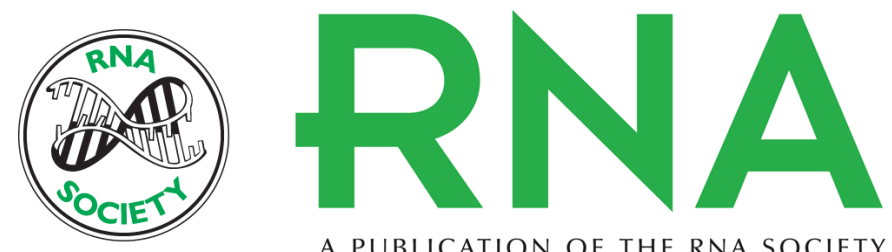

A PUBLICATION OF THE RNA SOCIETY

\section{The NMR structure of the II-III-VI three-way junction from the Neurospora VS ribozyme reveals a critical tertiary interaction and provides new insights into the global ribozyme structure}

Eric Bonneau, Nicolas Girard, Sébastien Lemieux, et al.

RNA 2015 21: 1621-1632 originally published online June 29, 2015

Access the most recent version at doi:10.1261/rna.052076.115

References This article cites 78 articles, 24 of which can be accessed free at: http://rnajournal.cshlp.org/content/21/9/1621.full.html\#ref-list-1

Creative This article is distributed exclusively by the RNA Society for the first 12 months after the Commons full-issue publication date (see http://rnajournal.cshlp.org/site/misc/terms.xhtml). After 12 License months, it is available under a Creative Commons License (Attribution-NonCommercial 4.0 International), as described at http://creativecommons.org/licenses/by-nc/4.0/.

Email Alerting Receive free email alerts when new articles cite this article - sign up in the box at the Service top right corner of the article or click here. 